\title{
Why Treatment of the Water Based Clay Slurries are Not Effective; the Microstructural Review
}

\author{
Marek SZ* \\ Department of Geology, University of Warsaw, Poland
}

Submission: October 24, 2017; Published: November 22, 2017

*Corresponding author: Marek SZ, Department of Geology, University of Warsaw, Poland, Email: marek.zbik@uw.edu.pl

\section{Introduction}

Clay minerals were formed as result of the weathering of volcanic glass, lavas and igneous rocks like granites and basalts. Clays are useful for dam bed impregnation, to improve water retention properties and as drilling mud, to seal the cut, thus preventing fluid loss. They are also popular stabilising additives in engine oils, cosmetics, pharmaceutical and chemical industries. Their water retention phenomenon prevents aggregates of clay-water suspension from settling under gravity force which cause difficulties in clay rich sludge dewatering. Dewatering of sludge by physical and chemical treatments becoming increasingly urgent in view of the growing demand for sites for the disposal of mining slurries, tailings and other mineral "wastes". Mine tailings are often disposed of as high water content slurries into tailing dams with harm for the natural environment and is very costly. Primary dewatering processes include aggregate formation, bridging flocculation, settling rate and bed height (density) before compression. This can be achieved by physico-chemical processes like aggregation, coagulation and flocculation which were clarified recently in [1]. Aggregation is usually understood as a process of formation larger and stable structural elements by primary particles connecting in Face to Face phase contacts and becoming unstable [2]. Coagulation is connected mostly with interaction between primary particles within dense suspensions (gels) resulting in Face to Edge (FE) and Edge to Edge (EE) coagulating type contacts. Flocculation also is seen as a process of building larger structural elements and some authors [2,3] relate this with coagulation. Others present flocculation as a separate type of coagulation to be achieved by flocculation using long chain polymers; however, this process is still not well understood.

To help understand micro structural behaviour of clay gelled suspension, the microstructure investigation was conducted using a Transmission X-ray Microscope (TXM) and cryo-SEM. The application of a high resolution TXM, has increased with the availability of synchrotron photon sources. In the soft X-ray range $(100 \mathrm{eV}-1 \mathrm{keV})$, a zone plate based TXM, has achieved a spatial resolution of $60 \mathrm{~nm}[4,5]$. In this article, we are using the microscope constructed in the National Synchrotron Radiation Research Canter (NSRRC).

All our results advocate [6-20], the structure building phenomenon within entire suspension may be blame for poor settling and dewatering. All these may be result of high water dielectric constant which polarising clay particles and generating electrostatic charge. This charge leads to structure building phenomenon within the aqueous suspensions. It becomes clear that further technologies have to eliminate using water in mineral processing and develop new approach involving close loop processing environment in low dielectric constant liquids (Figure 1).

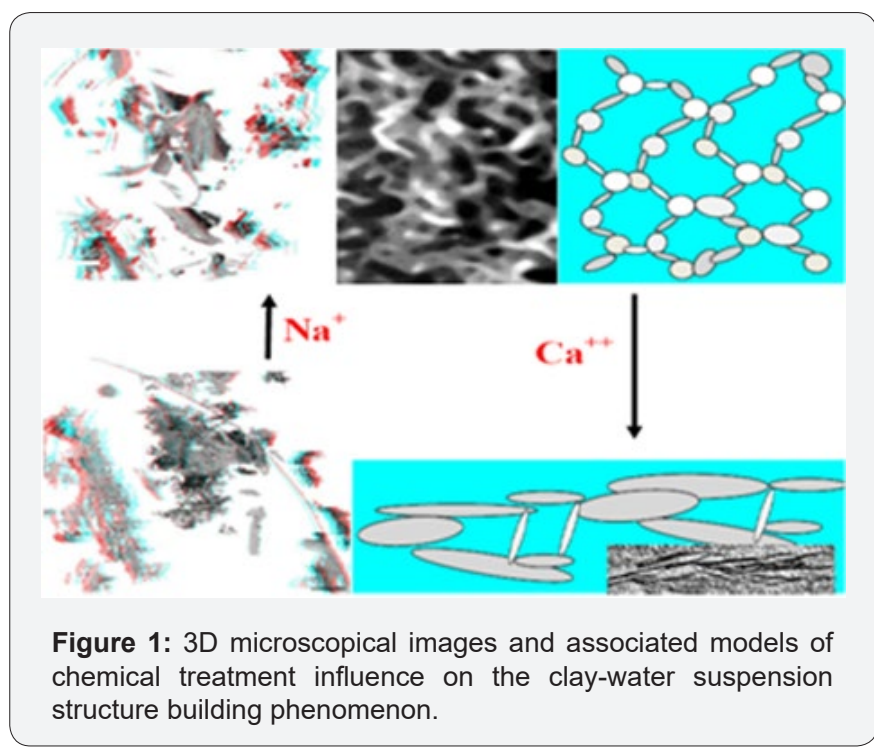

\section{References}

1. Osipov VI, Sokolov VN (2013) Clays and their properties. Composition, structure, and formation of properties. Moscow, Russia: GEOS p. 576.

2. Olphen VH (1963) An introduction to clay colloid chemistry. Willey A, Interscience Publ, New York, USA, p. 301. 
3. Mitchell JK, Soga K (2005) Fundaments of Soil Behavior. John Willey and Sons, New York, USA, p. 577.

4. Yin GC, Tang MT, Song YF, Chen FR, Liang KS, et al. (2006) Energytunable transmission $\mathrm{x}$-ray microscope for differential contrast imaging with near 60nm resolution tomography. Appl Phys Lett 88(24).

5. Attwood D (2006) Nanotomography comes of age. Nature 442(7103): 642-643.

6. Zbik MS, Frost RL, Song YF, Chen YM, Chen JH, et al. (2008) Transmission X-Ray Microscopy reveals the clay aggregate discrete structure in aqueous environment. J Colloid and Interface Sci 319(2): 457-461.

7. Zbik MS, Smart RSC, Morris GE (2008) Kaolinite Flocculation Structure. J Colloid and Interface Sci 328(1): 73-80.

8. Zbik MS, Martens W, Frost RL, Song YF, Chen YM, et al. (2008) Transmission X-ray Microscopy (TXM) reveals nano-structure of smectite Gel. Langmuir 24(16): 8954-8958.

9. Morris GE, Zbik MS (2009) Smectite suspension structural behaviour. Inter J Mineral Processing 93(1): 20-25.

10. Zbik MS, Frost RL (2009) Micro-structure differences in kaolinite suspensions. J Colloid Interface Sci 339(1): 110-116.

11. Zbik MS, Song YF, Chen YM (2009) Transmission X-ray Microscopy (TXM) Reveals 3-D Nano-structure of Clay-water Suspension. Activity Report Year 2008/2009. National Synchrotron Radiation Research Center, Taiwan, pp. 82-85.

12. Zbik MS, Martens W, Frost RL, Song YF, Chen YM, et al. (2010) Smectite flocculation structure modified by Al13 macromolecules; as revealed by the Transmission X-ray Microscopy (TXM). J Colloid Interface Sci 345(1): 34-40.

13. Zbik MS, Frost RL (2010) Influence of smectite suspension structure on sheet orientation in dry sediments: XRD and AFM applications. J Colloid Interface Sci 346(2): 311-316.

14. Żbik MS, Raftery NA, Smart RSC, Frost RL (2010) Kaolinite platelet orientation for XRD and AFM applications. Applied Clay Science 50(3): 299-304.

15. Żbik MS, Song YF, Frost RL (2010) Kaolinite flocculation induced by smectite addition- a transmission X-ray microscopic study. J Colloid Interface Sci 349(1): 86-92.

16. Zbik MS, Williams DJ, Song YF, Chun WCC (2014) The formation of a structural framework in gelled Wyoming bentonite: Direct observation in aqueous solutions. J Colloid Interface Sci 435: 119-127.

17. Zbik MS, Williams DJ, Song YF, Chun WCC (2015) Smectite clay microstructural behaviour on the Atterberg limits transition. Colloids and Surfaces A: Physicochem Eng Aspects 467: 89-96.

18. Zbik MS, Williams DJ, Song YF, Wang CC (2015) How the hydrogel flocculation microstructure changes. Colloids and Surfaces A: Physicochem Eng Aspects 469: 11-19.

19. Żbik MS, Williams DJ, Trzciński JT (2017) Micelle-like microaggregate morphology in framework of gelled montmorillonite. J Membr Sci Technol 7(1): 1-4.

20. Żbik MS, Williams DJ (2017) Influence of physical treatment on kaolinite floccule microstructure. Arch Pet Environ Biotechnol 2017(1).

This work is licensed under Creative Commons Attribution 4.0 Licens

DOI: 10.19080/RAPSCI.2017.03.555624
Your next submission with Juniper Publishers will reach you the below assets

- Quality Editorial service

- Swift Peer Review

- Reprints availability

- E-prints Service

- Manuscript Podcast for convenient understanding

- Global attainment for your research

- Manuscript accessibility in different formats

( Pdf, E-pub, Full Text, Audio)

- Unceasing customer service

Track the below URL for one-step submission https://juniperpublishers.com/online-submission.php 